\title{
РЕІНЖИНІРИНГ БІЗНЕС-ПРОЦЕСІВ ЯК СУЧАСНИЙ ІНСТРУМЕНТ УСПІШНОГО РОЗВИТКУ РЕСТОРАННОГО ГОСПОДАРСТВА
}

\section{BUSINESS PROCESS REENGINEERING AS A MODERN TOOL OF SUCCESSFUL DEVELOPMENT OF THE RESTAURANT INDUSTRY}

\author{
Д'яконова Анджела Костянтинівна \\ доктор технічних наук, профресор, \\ Одеський національний технологічний університет \\ ORCID: https://orcid.org/0000-0001-6895-0780 \\ Трішин Федір Анатолійович \\ кандидат технічних наук, доцент, \\ Одеський національний технологічний університет \\ ORCID: https://orcid.org/0000-0001-5994-3538 \\ Коротич Олена Миколаївна \\ асистент, \\ Одеський національний технологічний університет \\ ORCID: https://orcid.org/0000-0002-2680-976X
}

\author{
Dyakonova Andzhela, Trishyn Fedir, Korotych Olena \\ Odessa National Technological University
}

\begin{abstract}
Робота присвячена дослідженню розвитку ресторанного бізнесу, який вважається вагомою високоприбутковою складовою індустрії гостинності в Україні і світі. В сучасних умовах жорсткої конкурентної боротьби підприємствам ресторанного бізнесу дуже важко адаптуватися до швидких змін у зовнішньому економічному середовищі та збільшення вимогливості гостей ресторанних закладів. Тому все більшої актуальності і практичного значення набуває реінжиніринг бізнес-процесів, який базується на новому підході до ведення бізнеспроцесів, дає змогу вітчизняним підприємствам активно розвиватися і бути конкурентоспроможними як на внутрішньому, так і на зовнішньому ринку. У зв'язку з цим виникла необхідність у впровадженні у ресторанний бізнес інноваційних заходів та інформаційних технологій. Сучасні інорормаційні технології здатні суттєво змінити діяльність ресторанних закладів у відповідності до вимог ринку і очікування споживачів ресторанної продукції. В роботі досліджено практичний досвід використання інформаційних технологій при впровадженні принципів реінжинірингу бізнес-процесів підприємствами ресторанного бізнесу, проведено аналіз матеріальних і інфрормаційних потоків в діючих ресторанах, що дозволило отримати комплексну функціональну модель діяльності ресторанних закладів. Побудова фрункціональної моделі AS-IS дозволяє визначити, які процеси здійснюються на підприємствах ресторанного бізнесу, які інформаційні засоби використовуються, а також відображає взаємозв'язок етапів діяльності в ресторані між собою і вплив кожного етапу на кінцевий результат.

Ключові слова: ресторанний бізнес, реінжиніринг бізнес-процесів, конкурентоспроможність, інновації, інформаційні технології, функціональна модель діяльності ресторану.
\end{abstract}

Работа посвящена исследованию развития ресторанного бизнеса, который считается весомой высокоприбыльной составляющей индустрии гостеприимства в Украине и в мире. В современных условиях жесткой конкурентной борьбы предприятиям ресторанного бизнеса очень тяжело адаптироваться к быстрым переменам во внешней экономической среде и повышению требовательности гостей ресторанных заведений. Поэтому все большую актуальность и практическое значение приобретает реинжиниринг бизнес-процессов, который базируется на новом подходе к ведению бизнес-процессов, дает возможность отечественным предприятиям активно развиваться и быть конкурентноспособными как на внутреннем, так и на внешнем рынке. В связи с этим возникла необходимость во внедрении в ресторанный бизнес инновационных мероприятий и информационных технологий. Современные информационные технологии способны существенно изменить 
деятельность ресторанных заведений в соответствии с требованиями рынка и ожиданиями потребителей ресторанной продукции. В работе исследовано практический опыт использования информационных технологий при внедрении принципов реинжиниринга бизнес-процессов предприятиями ресторанного бизнеса, проведен анализ материальных и информационных потоков в действующих ресторанах, что позволило получить комплексную фрункциональную модель деятельности ресторанных заведений. Построение функциональной модели AS-IS позволяет определить, какие процессы выполняются на предприятиях ресторанного бизнеса, какие информационные средства используются, а также отображает взаимосвязь этапов деятельности в ресторане между собой и влияние каждого этапа на конечный результат.

Ключевые слова: ресторанный бизнес, реинжиниринг бизнес-процессов, конкурентоспособность, инновации, информационные техноло-гии, функциональная модель деятельности ресторана.

The paper considers the study of the development of the restaurant business, which is considered an important highly profitable component of the hospitality industry in Ukraine and in the world. In the current conditions of tough competition, it is very difficult for restaurant businesses to adapt to rapid changes in the external economic environment and increasing the demands of restaurant guests. Therefore, business process reengineering in restaurants is becoming increasingly relevant and practical, which is based on a new approach to doing business processes, allows domestic enterprises to actively develop and be competitive in both domestic and foreign markets for restaurant services. It has therefore become necessary to introduce innovative measures into the restaurant business, the most advanced of which are information restaurant technologies. Modern information technologies play a crucial role in business reengineering. They are the main tool for the formation of new opportunities for restaurant enterprises, the main factor in their success, which significantly change the activities of restaurants in accordance with modern market requirements and expectations of consumers of restaurant products. The introduction of information technologies allows restaurants to interact much more effectively with restaurant guests, suppliers of raw materials, to organize at a modern level the processes of obtaining and using food raw materials, cooking and providing quality services. The paper studies the practical experience of using information technologies in the implementation of the principles of business process reengineering by restaurants, analyses material and information flows in existing restaurants, which allowed obtaining a comprehensive functional model of the restaurant business. The construction of the AS-IS functional model allows to determine what processes are carried out in the restaurant business, what information tools are used, and reflects the relationship between the stages of the restaurant activities and the impact of each stage on the final result.

Keywords: restaurant business, business process reengineering, competi-tiveness, innovations, information technologies, functional model of the restaurant business.

Постановка проблеми. Розвиток сучасного суспільства значною мірою пов'язаний з виробництвом і споживанням різноманітних благ матеріального і соціального характеру, необхідних для забезпечення потреб населення країни. На сьогодні індустрія гостинності орієнтована на споживачів і задоволення їх потреб в умовах проживання, оздоровлення, відпочинку і розваг.

Готельно-ресторанне господарство займає одне із провідних місць у реалізації соціальноекономічних завдань, пов'язаних 3 діловою активністю населення країни, і $€$ найприбутковішим ринком в Україні і світі. Ресторан-ний бізнес вважається вагомою складовою індустрії гостинності. Це високоприбутковий, перспективний для інвестицій і привабливий для підприємців сегмент ринку послуг, який динамічно розвивається.

У багатьох країнах світу в цьому сегменті комерційної діяльності задіяний малий бізнес, власники якого ведуть постійну боротьбу за сегментацію ринку, пошук нових та утримання старих споживачів ресторанної продукції та послуг. Тому власники ресторанного бізнесу уважно слідкують за ринком збуту ресторан- ної продукції і вимушені підтримувати високий рівень конкурентоспроможності.

Слід відзначити, що в сучасних умовах мінливого економічного середовища на індустрію гостинності суттєво впливають зовнішні фрактори, а саме соціально-економічні зміни, що відбуваються у суспільстві. Тому заклади ресторанного господарства повинні швидко реагування на зміни, що відбуваються у суспільстві, та впроваджувати адекватні заходи у свою діяльність.

Стратегічно важливими дослідженнями компаній ресторанного бізнесу, які визначають подальшу діяльність закладу по створенню продукції, її виробництву, реалізації гостям і отримання прибутку, $є$ аналіз бізнессередовища, слідкування за його змінами, а також аналіз потреб споживачів.

Тому існує необхідність у впровадженні у ресторанний бізнес інноваційних заходів, інструментів та інфрормаційних технологій, які дозволять адаптуватися підприємству до нових умов зовнішнього середовища і ефективно реалізувати організаційно-управлінський та виробничий потенціал закладу на ринку збуту ресторанної продукції. Сучасні 
інфрормаційні технології здатні докорінно змінити бізнес-процеси і покращити основні показники діяльності організації у відповідності до запитів ринку та очікування споживачів ресторанної продукції.

На сьогодні провідні компанії індустрії гостинності заходу широко впроваджують принципи реінжинірингу бізнес-процесів, застосовуючи процесний підхід, який вважається сучасним науково-практичним напрямком використання інноваційних технологій у сорері гостинності, для забезпечення радикальної перебудови готельно-ресторанного бізнесу, підвищення ефективності виробництва і покращення обслуговування гостей, які потребують послуг ресторанного господарства.

Бізнес-процес - це комплекс послідовних дій, спрямованих на створення продукту або послуги, які задовольняють очікувані потреби споживача. Процесний підхід - це розгляд взаємопов'язаних процесів, що протікають усередині організаційної структури ресторанного господарства і реалізовують основну мету діяльності підприємства. Такий підхід реалізовано в стандарті ISO 9001:2000, де під бізнеспроцесом розуміють цілеспрямовану сукупність взаємопов'язаних видів діяльності (послідовність робіт), що перетворюють входи у виходи, які мають цінність для споживача [1, с. V].

Процесно-орієнтоване управління ресторанного господарства дозволяє визначитись 3 впровадженням ефеективних інсрормаційних технологій, спрямованих на підвищення якості обслуговування гостей ресторанного господарства. Використання інфрормаційних технологій може бути пов'язане як 3 принциповими змінами діяльності робітників підприємства, так і з повною заміною існуючих бізнес-процесів.

В сучасних ринкових умовах новітньою концепцією в управлінні ресторанним бізнесом $€$ реінжиніринг бізнес-процесів, який активно витісняє всі інші підходи, які використовувались у маркетинговій діяльності та менеджменту для підвищення конкурентоспроможності ресторанних закладів.

Реінжиніринг (BPR - англ. - business process reengineering) - це фрундаментальне переосмислення і радикальне перепроектування бізнес-процесів з метою кардинального поліпшення важливих поточних показників продуктивності, таких як витрати, якість і швидкість обслуговування. Засновниками теорії реінжинірингу є М. Хаммер і Дж. Чампі. Автори визначили реінжиніринг як фрундаментальне переосмислення і радикальне перепроектування бізнес-процесів для досягнення кардинального покращення в таких ключових для сучасного бізнесу показниках результативності як вартість, якість, сервіс і оперативність [2].

Актуальність статті пов'язана 3 дослідженням практичного досвіду використання інформаційних технологій при впровадженні принципів реінжинірингу бізнес-процесів підприємствами ресторанного господарства.

Аналіз основних досліджень і публікацій. Реінжиніринг бізнес-процесів $є$ найбільш радикальним маркетинговим управлінським заходом, використання якого можливе як в умовах кризи, так і в умовах успішної діяльності, для забезпечення певних конкурентних переваг ресторанному закладу і збільшення доходів від реалізації продукції [3, с. 126]. Він базується на ряді принципів, які дозволяють докорінно змінити базові правила роботи системи управління, до яких відносяться: доцільність; радикальні зміни; процесна орієнтованість; економічні вигоди; зниження сили дії бюрократичного апарату; ефрективна система мотивації роботи персоналу; взаємна відповідальність за наслідки бізнес-процесу; спрямованість на постійне задоволення потреб гостей ресторанного господарства тощо. Впровадження реінжинірингу бізнес-процесів стало можливим завдяки інформаційним технологіям і їх адаптації до сорери виробництва та управління.

3 розвитком ринкових відносин відбувається становлення і орормування конкурентного середовища в національній економіці. Підвищення конкуренції, прискорення темпів змін зовнішнього середовища викликали об'єктивну необхідність розроблення та втілення на українських підприємствах принципово нових підходів до управління ресторанним бізнесом, забезпечення конкурентоспроможності ресторанної продукції і формування стратегії підприємства на ринку збуту готової продукції.

Питанням реінжинірингу бізнес-процесів у ресторанному господарстві присвячені роботи значної кількості авторів: Розкошна В.А. і Гончарова Л.М. освітлюють питання щодо особливостей фрормування системи реінжинірингу бізнес-процесів як складової процесного управління в сучасних умовах ринкової нестабільності [4, с. 102]; Скуртол С.Д і Пархоменко Л.А. проведено узагальнення теоретичних питань, пов'язаних з систематизацією та впровадженням інформаційних технологій [5, с. 219]; Степановою Н.І. розглянуто сутність та види реінжинірингу бізнес-процесів як 
сучасного методу стратегічного управління підприємством, а також основні системи, етапи, послідовність та наслідки впровадження реінжинірингу на підприємстві [6, с. 22]; Данченко О.Б. викладено теоретичні та практичні аспекти технології реінжинірингу бізнес-процесів тощо [7]; Сандул Ю.О. проведено аналіз процесів обслуговування гостей в ресторанах і зроблено висновок, що якість обслуговування слід вважати дуже важливим фактором впливу на успішність у конкурентній боротьбі на ринку збуту ресторанної продукції [8, с. 547].

Більшість вітчизняних компаній, задіяних в ресторанному господарстві, використовують інфрормаційні технології для вирішення організаційних, управлінських та економічних проблем діяльності закладу. Кількість ресторанних закладів, які впроваджують інфрормаційні системи, постійно зростає.

Формулювання цілей статті (постановка завдання). Метою даної наукової публікації $\epsilon$ обґрунтування процесу здійснення реінжинірингу та фрормування системи бізнес-процесів розвитку ресторанного бізнесу на сучасному етапі діяльності.

Виклад основного матеріалу дослідження. Впровадження комплексу автоматизації відкриває для робітників ресторану всіх рівнів значну кількість можливостей, які змінюють стиль роботи закладу загалом. Наприклад, автоматизація виробництва допомагає шефр-кухару фрормувати меню, розрахувати вартість страв і економічні показники, які пов'язані з витратами сировини, енергоносіїв, води тощо. Автоматизація виробництва призводить до покращення роботи організаційних структур і фрункцій управління. Використання QR-кодів дозволяє ознайомитись 3 меню, акціями та отримати всю інформацію про ресторан. Заміна паперових меню на планшети дозволяє гостю ознайомитись зі складом страв, їх калорійністю, скоротити час обслуговування гостей у ресторані.

При автоматизації складського господарства і впровадженні логістики просування і витрат сировини значно спрощуються фрункції менеджера, який відповідає за постачання, зберігання і витрати продуктів та напівсрабрикатів.

Об'єднання матеріальних і інфрормаційних потоків $€$ однією з основних завдань сучасної логістики. На сучасному етапі розвитку інорормаційних систем використовують логістичні системи, що орієнтовані на планування потреб ресурсів: SCM, JIT, KANBAN MRP-1/ MRP-2 SDP, LP, LRP, DDT та ін. [9, с. 336]. Система JIT спрямована на максимальну інтеграцію всіх логістичних фрункцій підприємства для мінімізації рівня запасів матеріальних ресурсів в інтегрованій логістичній системі. Система KANBAN спрямована на своєчасне постачання чітко за графріком на всі виробничі ділянки саме тієї кількості матеріальних ресурсів, яка необхідна для випуску тільки запланованої продукції.

Особливість інформаційних технологій, які використовуються в ресторанному господарстві, пов'язана з тим, що системи автоматизації повинні враховувати фрункції управління виробничими процесами підприємства і фрункції управління сорерою послуг, тобто одночасно охоплювати процеси виготовлення і реалізації продукції гостям ресторанного закладу.

Сьогодні на ринку програмного забезпечення широко використовуються такі програмні комплекси, як «R-Keeper», «Магия», «Tillypad», «РCT: Ресторатор», «Эксперт» тощо. Всі перераховані системи для автоматизації ресторанного господарства мають приблизно однакові фрункції, але розрізняються кількістю охоплених бізнес-процесів.

При виборі інорормаційної системи (IC) для впровадження у своєму закладі, ресторатор віддає перевагу перевіреним системам автоматизації ресторанного бізнесу, які повинні забезпечувати можливість отримувати оперативну інформацію відносно фрінансового стану, оптимізувати закупівлю, витрати сировини і товарних запасів, швидко обслуговувати постійних відвідувачів і допомагати залучати нових гостей закладу тощо.

Впровадження IC і автоматизація поточних бізнес-процесів спрямовані на скорочення об'єму ручної праці і зменшення кількості зловживань з боку персоналу, суворий облік і контроль пересування всіх матеріальних цінностей в межах закладу, дотримання технології виробництва страв за технологічними картами, автоматизований розрахунок собівартості готової продукції, що значно спрощує оцінку ефективності роботи виробничих цехів і закладу в цілому.

Таким чином, впровадження інорормаційних технологій в ресторанному бізнесі дозволяє значно скоротити тривалість обслуговування гостей закладу, ефрективно слідкувати за роботою підприємства, аналізувати отримані данні і своєчасно реагувати на зміни, які відбуваються в соціально-економічному просторі та конкурентному середовищі ресторанного бізнесу. Ефективність використання інорормаційних технологій значно підвищує 
економічну ефрективність роботи закладів ресторанного господарства.

Розробники інформаційних технологій для ресторанного бізнесу пропонують велику кількість програм, які спрямовані на еластичність розрахунків з відвідувачами ресторану. Наприклад, програма «R-Keeper» пропонує кілька способів розрахунків з гостями ресторану. До них відноситься кредитування гостя 3 встановленням певного ліміту, перевищення якого автоматично включає припинення обслуговування гостя до погашення заборгованості або поповнення на суму кредитування [10].

Як відомо, бізнес-процеси ресторанного господарства - це ланцюжок різних взаємопов'язаних видів діяльності, які перетворюють вхідні потоки закладу, до яких відносяться матеріальні ресурси, гості закладу, інноваційні та інфрормаційні технології, в кінцевий продукт, який має цінність для споживачів ресторанної продукції, і потребує послуг ресторанного господарства. Слід відзначити, що кожне діюче підприємство розглядається як система, що базується на реалізації взаємопов'язаних процесів, які в сукупності визначають стан і конкурентоспроможність всієї організаційної системи.

Сукупність бізнес-процесів виробництва і сервісних послуг забезпечує досягнення необхідного результату, а саме задоволення гостей закладу і отримання прибутку. Стабільність фрункціонування ресторанного господарства на ринку надання послуг значною мірою визначається асортиментом страв і використаної сировини, складеним меню і наданими послугами, які забезпечують успішність у конкурентній боротьбі на ринку збуту ресторанної продукції. Для ресторанів меню вважається їх візитною карткою, а створення меню $€$ потужним маркетинговим інструментом у реалізації продукції ресторану.

На сьогодні кожне ресторанне господарство для успішного бізнесу прагне автоматизувати всі бізнес-процеси, тобто перевести типові бізнес-процеси під контроль програмно-апаратного комплексу, що дозволяє підвищити ефрективність управління, оптимізувати діяльність підприємства, скоротити витрати ресурсів, підвищити продуктивність праці і рівень обслуговування гостей закладу. Для досягнення успіху в ринковій економіці ресторанні господарства повинні активно використовувати інновації в обслуговуванні гостей закладу і впроваджувати інфрормаційні системи управління.
В ресторанах, які користуються попитом i де збирається велика кількість відвідувачів, які бажають відпочити і отримати задоволення від їжі і обслуговування, важко контролювати прийом і обробку замовлень на високому рівні. Цю проблему можна вирішити шляхом впровадження інформаційних технологій бізнес-процесів по обслуговуванню гостей ресторанного закладу на основі принципів реінжинірингу бізнес-процесів. До головного фрактору підвищення ефективності ресторанного бізнесу відноситься якість наданих послуг гостям закладу, що є однією з проблем ресторанного господарства і значною мірою впливає на статус підприємства. Аналізуючи мате-ріальні і інформаційних потоки в діючих ресторанах, отримано комплексне уявлення про діяльність ресторанного господарства в цілому для створення основних фрункціональних моделей діяльності ресторанних закладів і їх подальшої деталізації. Функціональна модель необхідна для відображення функціонування роботи системи ресторанного закладу і її взаємозв'язків з внутрішніми і зовнішніми елементами. Для грасрічного відображення цих моделей використовують блок-схеми, які відображають бізнес-процеси діяльності ресторанного закладу і показують взаємозв'язки при фрункціонуванні ресторанного закладу. Функціональна модель призначена для дослідження особливостей роботи системи і показати її зв'язки з внутрішніми і зовнішніми елементами, від яких залежить робота системи в цілому.

Функціональне моделювання - це процес моделювання фрункцій, що виконуються системою або об'єктом шляхом створення описового, структурованого, графрічного зображення, яке показує що, як і ким виконується в межах фрункціонування об'єкта, що пов'язують ці фрункції із врахуванням наявної інорормації.

Для побудови бізнес-моделі використовують різні інструментальні засоби і методології. Для впровадження реінжинірингу бізнес-процесів у сорері гостинності найбільш доцільно використовувати методологію структурного аналізу і проектування (SADT), або розроблене на їі базі сімейство методологій IDEF, що є державним стандартом в США. Основною перевагою методології IDEFO $€$ відповідність представлення процесу в IDEFO визначенню процесу у МC ICO 9000:2000, що дозволяє використовувати IDEF0 в якості внутрішнього стандарту організації, який регламентує опис бізнеспроцесів [11]. 
Основними блоками функціональної моделі ресторану є: «Організація робочого процесу», «Вибір постачальника», «Закупівля продуктів», «Надання послуги гостям ресторану».

Для побудови моделі діяльності ресторанного господарства використали нотацію бізнес-процесів IDEF0, яка $€$ нотацією графрічного моделювання і використовується для створення фрункціональної моделі, що відображає структуру і фрункції системи ресторанного бізнесу в цілому, а також потоки інформації і матеріальних засобів, які задіяні в бізнес-процесах.

Моделювання процесів у нотації IDEFO починається зі створення контекстної діаграми, яка описує діяльність організації або виділеного процесу в цілому. На контекстній діаграмі відображаються найважливіші входи і виходи, механізми, необхідні для виконання роботи, а також керуючі дії. IDEF0 - це контекстна або верхня діаграма, на якій об'єкт моделювання, а саме ресторанний бізнес, представлений єдиним блоком з граничними стрілками. Вона відображає зв'язки об'єкту моделювання 3 навколишнім середовищем. Ця діаграма називається А-0 (рис. 1).

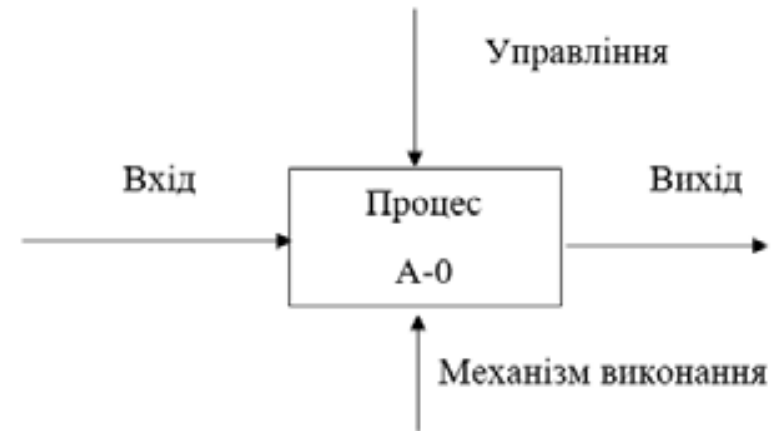

Рис. 1. Контекстна діаграма процесу «надання ресторанних послуг» в нотації IDEF0 Джерело: складено авторами та за джерелом [11]

Процес реінжинірингу бізнес-процесів складається 3 кількох етапів: опис існуючої організаційної системи (AS-IS); формування матриці процесу (AS-IS); моделювання існуючого бізнес-процесу в нотації IDEF (AS-IS); проведення фрункціонально-вартісного аналізу бізнес-процесу (AS-IS); прийняття рішень щодо змінення бізнес-процесу; моделювання майбутнього бізнес-процесу в нотації IDEF (TO-BE); проведення функціонально-вартісного аналізу бізнес-процесу (TO-BE); формування нової матриці відповідальності процесу (ТО-ВЕ); побудова нової організаційної структури (TO-BE).

Функціонально модель AS-IS - це модель «як є», тобто модель вже існуючого процесу або функції. Аналіз процесів $€$ обов'язковою частиною будь-якого проекту створення нової або розвитку існуючої системи. Вона призначена для вивчення особистостей роботи ресторанного господарства як системи і їі взаємозв'язків з внутрішніми і зовнішніми елементами, пов'язаними з роботою закладу.

Побудова фрункціональної моделі AS-IS дозволяє визначити, які процеси здійснюються на підприємстві ресторанного господарства, а також які інфрормаційні об'єкти використовуються при виконанні функцій різного рівня деталізації. Вона показує, як взаємопов'язані етапи діяльності в ресторані між собою, і як кожен етап впливає на кінцевий результат.

Функціональна модель AS-IS $€$ відправною точкою для аналізу роботи підприємства, виявлення проблем для розробки проекту вдосконалення бізнес-процесів. Аналіз фрункціональної моделі AS-IS дозволяє зрозуміти, в чому полягає проблема, в чому будуть полягати переваги нових процесів і яким змінам піддасться існуюча структура процесу в результаті оптимізації. Особлива складність реінжинірингу бізнес-процесів пов'язана 3 тим, що в процесі ресторанного бізнесу задіяна значна кількість різних бізнес-процесів, які взаємовпливають один на одного.

Стрілки на діаграмі відображають зв'язки об'єкту моделювання 3 навколишнім середовищем - споживачами, постачальниками, виконавцями тощо. Діаграма А-О або контекстна діаграма встановлює область моделювання та іï межі. Нотація IDEF0 деталізує послідовну декомпозицію процесу за допомогою деталізованих до необхідного рівня дочірніх діаграм.

Контекстна діаграма включає тільки один блок, який характеризує сукупність процесів, що моделюються.

Функція «вхід» включає наступні процеси: постачання харчової сировини і гастрономічних продуктів і напоїв; замовлення на бронювання столика в ресторані; зустріч гостя; приймання замовлення гостя; спосіб розрахунку гостя; інноваційні і інформаційні технології, що використовуються в ресторані.

Функція «управління» охоплює наступні елементи: державні накази; стандарти; постанови і розпорядження керівництва закладу; методи і правила виконання послуг; методи контролю якості і безпечності готової продукції; методи контролю наданих послуг.

Функція «механізм виконання» включає елементи: офріціанти; кухарі; бармен; обладнання та технічні засоби, що використову- 


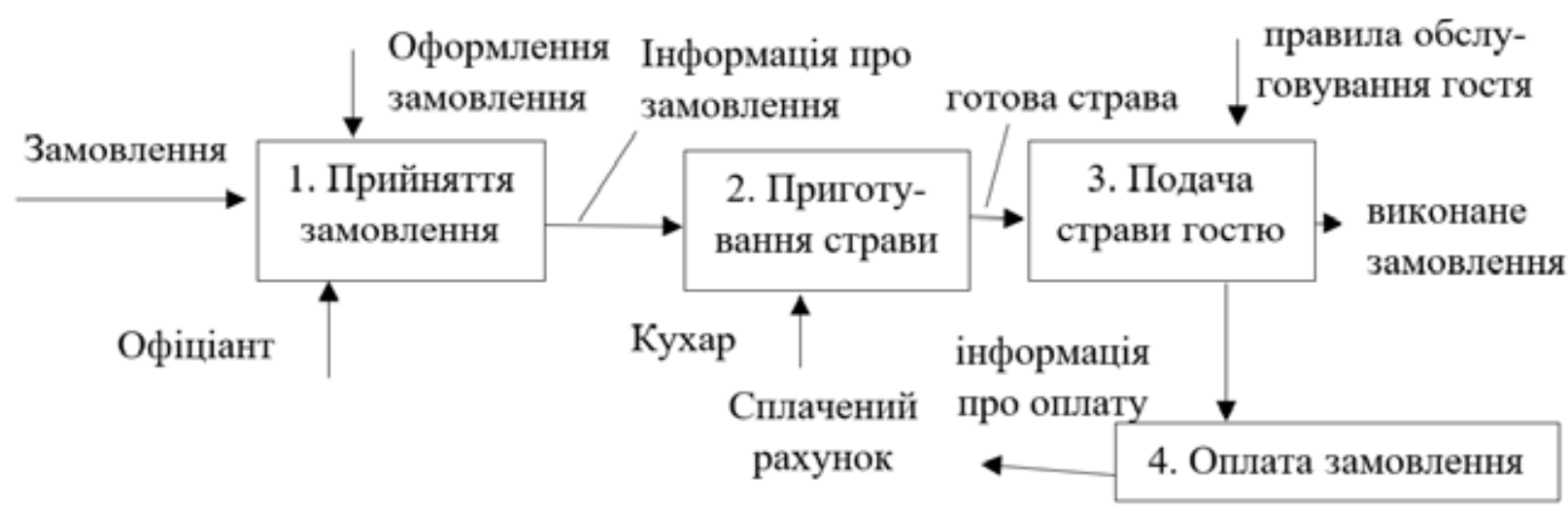

Рис. 2. Декомпозиція контекстної діаграми в нотації IDEF «надання ресторанних послуг» Джерело: складено авторами та за джерелом [11]

ється для виконання замовлення і надання послуг; приготування страв.

Функція «вихід» охоплює наступні процеси: виконане замовлення; оплачений розрахунок за надані послуги; ступінь задоволення гостя.

Таким чином, фрункція бізнес-процесів ресторанних послуг дозволяє чітко визначити потреби гостя при замовленні, які фрункції, в якій послідовності і ким виконуються процеси надання послуг. Результатом виконання бізнес-процесів закладів ресторанного господарства є задоволений гість і фрінансові надходження для закладу. Зовнішнім середовищем для ресторанного господарства $€$ постачальники матеріальних ресурсів, а також інші ресторанні заклади, що складають конкуренцію.

До блоку «надання ресторанних послу» входять наступні основні ффункції: прийняти замовлення від гостя; приготування страви; подача страви гостю; прийняти оплату за замовлення.

Декомпозиція контекстної діаграми «надання ресторанних послуг» наведена на рис. 2.

Входом в перший блок «Прийняти замовлення від гостя» $€$ гості, управління - посадові інструкції для обслуговуючого персоналу, механізм виконання замовлення - офріціант, вихід - замовлення.
Входом в другий блок «Приготування страви» $€$ замовлення, управління - кухарі, механізм - посадові інструкції, вихід - виконане замовлення.

Входом в третій блок «Подача страви» $€$ виконане замовлення, управління - посадові інструкції, механізм - офріціант, вихід - задоволений гість.

Входом в четвертий блок $є$ рахунок, управління - економічні засади, механізм - сплачений рахунок, вихід - отриманий прибуток.

Висновки. Досліджено практичний досвід використання інсрормаційних технологій при впроваджені принципів реінжинірингу бізнеспроцесів у ресторанному господарстві. Обґрунтовано необхідність використання принципів реінжинірингу бізнес-процесів в діяльності ресторанного господарства для підвищення конкурентоспроможності ресторанного закладу в сучасних економічних умовах. Проведено аналіз процесів обслуговування гостей в ресторанних закладах. Розглянуто методи і моделі, при використанні яких можна удосконалити процеси обслуговування на підприємствах ресторанного бізнесу. Визначено входи і виходи в системі обслуговування, що $є$ основою для подальшої декомпозиції і моделювання процесів обслуговування гостей ресторанного закладу.

\section{СПИСОК ВИКОРИСТАНИХ ДЖЕРЕЛ:}

1. ДСТУ ISO 9001:2009. Системи управління якістю. Вимоги. (ISO 9001:2008, IDT) [Чинний від 01.09.2009]. Вид. офріц. Київ : Держспоживстандарт України, 2009. 26 с.

2. Хаммер М., Чампи Дж. Реинжиниринг корпорации: Манифест революции в бизнесе. Москва : Манн, Иванов и Фербер, 2011. 276 с.

3. Ковальчук Т.Г. Перспективи розвитку готельно-ресторанного бізнесу в Україні в умовах глобалізації світового господарства. Науковий вісник Ужгородського національного університету. 2019. Вип. 23. Ч. 1. C. $126-130$.

4. Розкошна О.А., Гончарова М.Л. Особливості формування системи реінжинірингу бізнес-процесів. Академічний огляд. 2011. № 1(34). С. 102-106. 
5. Скуртол С.Д., Пархоменко Л.А. Створення та застосування інформаційних систем на підприємствах. Вісник Одеського національного університету ім. І.І. Мечнікова. 2016. Т. 21. Вип. 5(47). С. $219-222$.

6. Степанова Н.І. Реінжиніринг бізнес-процесів як інструмент покращення економічного стану підприємств. Управління розвитком. 2013. № 20. С. 22-24.

7. Данченко О.Б. Практичні аспекти реінжинірингу бізнес-процесів : навч. пос. Київ : Університет економіки та права «КРОК», 2017. 238 с.

8. Сандул Ю.О., Замула А.А. Анализ и моделирование процессов обслуживания клиентов в ресторане. Инфрормационные управляющие системы и компьютерный мониторинг : мат-лы IV Междунар. науч-практ. конфр., Донецк, 24-25 апреля 2014 г. 2014. Т. 1. С. 547-553.

9. Плескач В.Л., Затонацька Т.Г. Інформаційні системи і технології на підприємствах : підручник. Київ : Знання, 2011. 718 с.

10. Автоматизация ресторанов - ресторанная система R-Keeper. URL: https://rkeeper.com/ (дата звернення: 20.07.2021).

11. Марка Д.А., МакГоуэн К.Л. Методология структурного анализа и проектирования / [Пер. с англ.] Москва, 1993. $240 \mathrm{c}$.

\section{REFERENCES:}

1. Sistemi upravlinnya yakistyu. Vimogi [Quality management systems. Requirements] (2009) DSTU ISO 9001:2009 from 01 ${ }^{\text {st }}$ September 2009. Kyiv: Derzhspozhivstandart Ukrayini. (in Ukrainian)

2. Hammer, M. \& Champi, Dzh. (2011) Reinzhiniring korporacii: Manifest revolyucii v biznese [Corporate Reengineering: A Manifesto of the Business Revolution]. Moscow: Mann, Ivanov i Ferber. (in Russian)

3. Kovalchuk, T.G. (2019) Perspektivi rozvitku gotelno-restorannogo biznesu v Ukrayini v umovah globalizaciyi svitovogo gospodarstva [Prospects for the development of hotel and restaurant business in Ukraine in the context of globalization of the world economy]. Naukovij visnik Uzhgorodskogo nacionalnogo universitetu - Scientific Bulletin of Uzhhorod National University, vol. 23, 1, 126-130. (in Ukrainian)

4. Rozkoshna, O.A. \& Goncharova, M.L. (2011) Osoblivosti formuvannya sistemi reinzhiniringu biznes-procesiv [Features of formation of system of reengineering of business processes]. Akademichnij oglyad-Academic review, 1(34), 102-106. (in Ukrainian)

5. Skurtol, S.D. \& Parhomenko, L.A. (2016) Stvorennya ta zastosuvannya informacijnih sistem na pidpriyemstvah [Creation and application of information systems at enterprises]. Visnik Odeskogo nacionalnogo universitetu im. I.I. Mechnikova - Bulletin of Odessa National University. I.I. Mechnikov, vol. 21, 5(47), 219-222. (in Ukrainian)

6. Stepanova, N.I. (2013) Reinzhiniring biznes-procesiv yak instrument pokrashennya ekonomichnogo stanu pidpriyemstv [Business process reengineering as a tool to improve the economic condition of enterprises]. Upravlinnya rozvitkom - Development management, 20, 22-24. (in Ukrainian)

7. Danchenko, O.B. (2017) Praktichni aspekti reinzhiniringu biznes-procesiv [Practical aspects of business process reengineering]. Kyiv: KROK University of Economics and Law. (in Ukrainian)

8. Sandul, Yu.O. \& Zamula, A.A. (2014) Analiz i modelirovanie processov obsluzhivaniya klientov $v$ restorane [Analysis and modeling of customer service processes in the restaurant]. Proceedings from Information control systems and computer monitoring '2014: IV Mezhdunarodnaia nauchnoprakticheskaia konferentsiia (24-25 aprelya 2014 goda) - 4th International Scientific and Practical Conference, pp. 547-553. Doneck. (in Russian)

9. Pleskach, V. L. \& Zatonacka T.G. (2011) Informacijni sistemi i tehnologiyi na pidpriyemstvah [Information systems and technologies in enterprises]. Kyiv: Znannya. (in Ukrainian)

10. Avtomatizaciya restoranov - restorannaya sistema R-Keeper [Restaurant automation - restaurant system R-Keeper]. rkeeper.com. Retrieved from: https://rkeeper.com/ (in Russian)

11. Marka, D. \& Mcgouin, K. (1993) Metodologiia strukturnogo analiza i proektirovaniia [Methodologies of structural analysis and projection]. Moscow. (in Russian) 